\title{
Christoph Böttigheimer, Johannes Hofmann (red.), Autorität und Synodalität. Eine interdisziplinäre und interkonfessionelle Umschau nach ökumenischen Chancen und ekklesiologischen Desideraten Frankfurt am Main, Verlag Otto Lembeck 2008, 382 s.
}

W 2008 roku ukazała się w wydawnictwie Otto Lembeck we Frankfurcie nad Menem bardzo cenna z ekumenicznego punktu widzenia pozycja: Autorytet i synodalnośc. Międzydyscyplinarny i międzywyznaniowy przegląd ekumenicznych szans $i$ kościelnych dezyderatów. Jest to pokłosie sympozjum zorganizowanego przy Katolickim Uniwersytecie w Eichstätt-Ingolstadt w dniach 14-16 listopada 2007 roku. Tematyka wygłoszonych referatów nawiązywała bezpośrednio do międzywyznaniowego dialogu pomiędzy Kościołem prawosławnym a katolickim, a zwłaszcza dotyczyła ona spotkań Komisji do spraw dialogu, które miały miejsce w Belgradzie w 2006 roku i w Rawennie w 2007 roku. Tematyką tych obu spotkań były: wspólnota kościelna, synodalność ${ }^{1}$ i autorytet. Stąd też całość materiału sympozjum zebranego w prezentowanej tu książce podzielono na trzy części: Autorytet, Synodalność, a trzecia część przedstawia oba zagadnienia we wzajemnej zależności. Referaty na sympozjum głosili przedstawiciele Kościołów tak katolickiego jak i prawosławnego, ponadto przedstawiciele Kościoła unickiego Ukrainy, jak też przedstawiciele Kościołów protestanckich. Autorzy referatów reprezentują różne dziedziny wiedzy: biblistykę, teologię patrystyczną, teologię dogmatyczną, historię Kościoła, prawo kanoniczne tak katolickie jak wschodnie. Już sama różnorodność dziedzin wiedzy i różnorodność wyznaniowa reprezentowanych przez prelegentów nadawała sympozjum, a teraz zebranym w pozycji książkowej referatom, nadaje wysoką wartość podjętego dzieła. Tak więc wszystkie referaty oparte o głęboką wiedzę Autorów, mają swoją ekumeniczną wymowę. Nie sposób jednak je wszystkie omówić. Wskażemy na tematy najczęściej podejmowane i najbardziej dyskutowane.

Najwięcej miejsca na sympozjum, a potem w opublikowanej pozycji książkowej, poświęcono „autorytetowi”, pod którym, gdy chodziło o Kościół katolicki, rozumiano przeważnie prymat papieża. Prymat papieża - biskupa Rzymu kształtował się w pierwotnym chrześcijaństwie powoli, ale bardzo wyraźnie na bazie budowania kościelnej komunii, której zasadniczym zwornikiem był biskup Rzymu. Temat rozwoju i umacnianiu się autorytetu (prymatu) biskupa Rzymu w pierwszych pięciu wiekach chrześcijaństwa ukazuje w sposób udoku-

1 W prezentowanej pozycji używa się słowa „Synodalitat”, które w Kościołach wschodnich słowiańskich określa się mianem „soborność”. 
mentowany Johannes Hofmann, profesor starożytnej historii Kościoła i teologii patrystycznej Uniwersytetu w Eichstätt ${ }^{2}$.

Jeden z opublikowanych dokumentów Komisji Kościoła prawosławnego i katolickiego ds. dialogu, na który powołuje się w swoim opracowaniu Ch. Böttigheimer, na temat biskupstwa w Kościele, a w tym prymatu biskupa rzymskiego, uwzględniając różnice w rozumieniu prymatu w obu Kościołach, kończy wielce obiecującym zdaniem: „Biorąc pod uwagę wspólnotę lokalnych Kościołów można temat prymatu w całym Kościele, a przede wszystkim temat prymatu biskupa Rzymu, podjąć $\mathrm{z}$ uwzględnieniem potrzeby dalszej dyskusji, powinna być przedstawiona zasadnicza różnica pomiędzy nami, aby później móc ją

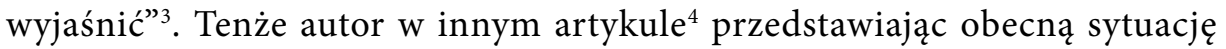
ekumenicznego dialogu idącego w trzech kierunkach, tzn. dyskusji dotyczącej autorytetu soborowego, biskupiego i prymatu papieskiego zaznacza, że wyłania się możliwość porozumienia pomiędzy Kościołami katolickim, prawosławnym i luterańskim. I tak Böttigheimer cytuje znaczącą wypowiedź greckiego teologa, E. Theodorou: „Jeżeli nauczanie i instytucje rzymsko-katolickiego bratniego Kościoła (np. nauczanie o jurysdykcyjnym prymacie papieża i o jego nieomylności) odstąpią od wymagania powszechnej ważności i skuteczności, zdewaluują je i osłabią ich wymowę poprzez symboliczną wykładnię i interpretację, a która swoją ważność zachowałaby w obrębie Kościoła katolickiego, to byłoby możliwe - moim zdaniem - tę symboliczną interpretację - na rzecz jedności - potraktować ze strony prawosławnych teologów jako w pewnym sensie nośną" ". Podobnie w przyjętym przez Mieszaną katolicko-prawosławną Komisję ds. Dialogu z 13 X 2007 roku w Rawennie, stwierdza się, „że Rzym jako Kościół, który według św. Ignacego z Antiochii «przewodzi w miłości», zajął pierwsze miejsce w szacunku i dlatego biskup Rzymu był pierwszy (protos) spośród patriarchów". Stąd połączenie synodalnej zasady dla poszczególnych Kościołów lokalnych z urzędem biskupa Rzymu jako służby wspólnocie i jedności całego Kościoła Komisja Mieszana ds. Dialogu wcale nie wyklucza ${ }^{6}$.

Także luteranie dają do zrozumienia, że byliby skłonni przyjąć biskupa Rzymu jako reprezentanta całego chrześcijaństwa, o ile byłby zaakceptowany system autokefaliczny, tzn. ogólnokościelnej koinonii siostrzanych Kościołów, a w niej przysługiwałoby biskupowi Rzymu honorowe przewodnictwo jako primus inter pares ${ }^{7}$.

\footnotetext{
2 J. Hofmann, Communio - Prüfstein personaler uns synodaler Autorität im Kontext kirchlich rezipierter Sunoden der ersten fünf Jahrhunderte?, s. 79-107.

3 Ch. Böttigheimer, Einführung zur ökumenischen Situation, s. 14 (s. 13-17).

4 Tenże, Kirchliche Autorität im ökumenischen Dialog. Konziliare, episkopale und primatiale Autoritäts-ausübung: Gemeinsamkeiten und Divergenzen, s. 23-47.

Tamże, s. 39.

Tamże, s. 39-40.

Tamże, s. 40.
} 
Ale, jak stwierdza Ch. Böttigheimer, narazie droga do głębszych relacji i ustaleń jest wciąż daleka i traktowanie Kościołów chrześcijańskich jako communio wyraża się raczej dzisiaj lepiej jako communicatio ${ }^{8}$.

Pierwsza część omawianej tu pozycji zawiera wiele wartościowych opracowań, które najlepiej by było przetłumaczyć dla polskiego Czytelnika w całości na język polski. Do takich opracowań należy zaliczyć artykuł profesor Theresia Hainthaler: „Autorytet i autorytety w starożytnym Kościele. Patrystyczne uwagi odnośnie do dokumentu z Rawenny"'. Theresia Hainthaler odwołuje się do dokumentu z Rawenny, gdzie wyjaśnia się również terminy m.in. „autorytet”: „Autorytet Kościoła pochodzi od jego Pana i Głowy Jezusa Chrystusa” (por. Ef $1,22 ; 5,23)$. Dalej celem „autorytetu” w Kościele jest jednoczyć całą ludzkość w Jezusie Chrystusie (Ef 1, 10; J 11, 52) Jest on przeznaczony do służby (diakonia) wspólnocie. Dokument z Rawenny, jak pisze T. Hainthaler, wskazuje na to, że „autorytet w kościelnej communio jest powiązany z zasadniczymi strukturami Kościoła, do których należą wyznanie wiary, sprawowanie sakramentów dzięki sukcesji apostolskiej (...). Tak jak communio w sakramentach zakłada communio w tej samej wierze, tak też musi zaistnieć pełna kościelna communio pomiędzy Kościołami przy jednoczesnym uznaniu kanonicznego prawodawstwa w ich prawowitej różnorodności” ${ }^{10}$. Theresia Hainthaler dokumentuje swoją interpretację dokumentu z Rawenny wielu wypowiedziami Ojców Kościoła, co czyni ją praktycznie niepodważalną. I jak echo powtarza się w dokumencie z Rawenny, że communio jest kryterium i miejscem wykonywania autorytetu. To w ramach uporządkowanej wspólnoty zgodnie z normami prawa kanonicznego dokonuje się posłannictwo każdego Kościoła wspieranego łaską Bożą, aby służyć Bogu i oddawać Mu chwałę, staje się miejscem głoszenia Ewangelii i sprawowania sakramentów, miejscem, w którym wierni dokładają starań, by ulżyć doli potrzebujących i gdzie każdy może osiągnąć zbawienie (19 pkt. dokumentu z Rawenny). Dokument podkreśla także, że charyzmaty poszczególnych wiernych i posługi w Kościele łączą się we wspólnocie, której przewodniczy biskup, a który z kolei służy jedności Kościoła lokalnego ${ }^{11}$.

Warto zwrócić uwagę na mocowanie się prawosławnej teologii o uznanie nośników kościelnego nauczania wobec wyzwań trzeciego Tysiąclecia, czym się zajął A. Vletsis ${ }^{12}$. Uznawanie przez większość Kościołów prawosławnych autorytetu znajdującego się w gestii synodów, w przeciwieństwie do prymatu

\footnotetext{
8 Tamże, s. 41.

9 T. Hainthaler, Autorität und Autoritäten in der Alten Kirche. Praktische Anmerkungen zum Ravenna-Dokument, [w:] Autorität und Synodalität, dz. cyt., s. 49-77.

10 Tamże, s. 51.

11 Tamże, s. 59.

12 A. Vletsis, Das Ringen der orthodoxen Theologie um die Erkenntnis um die Träger der kirchlichen Lehre von der Herausforderung des dritten Milleniums, [w:] Autorität und Synodalität, dz. cyt., s. 147-167.
} 
papieża w Kościele katolickim, poddawane jest, zwłaszcza w ekumenicznym dialogu, dyskusji. Prawosławni, jak np. A. Kallis, na którego powołuje się Vletsis, postulują rozróżnienie pomiędzy dwoma pojęciami: „autorytet” i „autentyczność, z których to ostatnie oznaczałoby bazowanie na prawdzie zachowywanej w tradycji, wbrew „katolickiej monarchicznej strukturze Kościoła czy też protestanckiemu antyinstytucjonalnemu, duchowemu wyobrażeniu Kościoła" ${ }^{13}$. Jednakże Vletsis prezentuje różnorodność prawosławnej teologii, wychodząc od autorytetu „ex sese” postanowień ekumenicznych soborów aż do rozumienia go „ex consensu Ecclesiae."

W trzeciej części warte zauważenia jest rozumienie autorytetu i synodalności w KPK z 1983 przedstawione przez S. Haeringa ${ }^{14}$. KPK pod pojęciem auctoritas rozumie raczej prawowitą i właściwą instancję, która wypełnia kościelną władzę. Natomiast, gdy chodzi o synodalność, a w KPK mówi się raczej o synodach, to rozumie się je (synody) w ścisłym znaczeniu jako zgromadzenie biskupów, którzy poprzez kolegialnie podejmowane decyzje, wypełniają kościelny obowiązek nauczania i zarządzania. Jako członkowie uczestnicy synodów są brani pod uwagę także osoby niebędące biskupami, jednakże bez prawa głosu. Tak więc synody w najnowszym KPK z 1983 roku mają charakter typowo biskupi ${ }^{15}$. Autor cytowanego artykułu wylicza różne synodalne formy funkcjonujące w Kościele katolickim. Są to synody we właściwym znaczeniu: sobór ekumeniczny (KPK kan. 330-367), synody partykularne (kan. 439-446) i do tego zalicza on konferencje biskupów (kan. 447-459), jak też synody w szerszym znaczeniu: synody biskupów, synody diecezjalne, wszelkiego rodzaju rady - każda $\mathrm{z}$ tych ostatnich form ze zróżnicowanymi kompetencjami. Po bliższym przedstawieniu różnych form synodalnych, autor stwierdza, że autorytet i synodalność w Kościele łacińskim nie są sobie przeciwstawne, są raczej związane ze sobą i w wielu przypadkach zależą od siebie. Ukazuje również, że w Kościele katolickim zasadą i fundamentem jedności całego Kościoła jest papież, a zasadą i fundamentem Kościołów lokalnych jest biskup.

Interesujące zasady posiadają katolickie Kościoły wschodnie uwidocznione przez A. Weissa $\mathrm{w}$ artykule o znaczeniu autorytetu i synodalności w prawie kanonicznym tychże Kościołów ${ }^{16}$. Autor podkreśla, że w katolickich Kościołach wschodnich uznaje się dwa niepodważalne podmioty: wspólnotę wierzących i sakrament święceń, będący podstawą urzędu przewodzącego lokalnemu Kościele. Formami synodalnymi są: synod biskupi w ramach patriarchatu, Synod

13 Tak Kallisa cytuje Vletsis, tamże, s. 147.

14 S. Haering, Autorität und Synodalität im Gesetzbuch der lateinischen Kirche, [w:] Autorität und Synodalität, dz. cyt., s. 297-320.

15 Tamże, s. 299.

16 A. Weiss, Die Zordnung von Autorität und Synodalität im CCEO, , [w:] Autorität und Synodalität, dz. cyt., s. 361-377. 
Stały i Konwent Patriarchalny. Członkami synodów Kościołów wschodnich są biskupi, świeccy mogą być doradcami.

Reasumując, można powiedzieć, że ukazywana tu pozycja jest ze wszech miar cennym przyczynkiem w dialogu międzykonfesyjnym w chrześcijaństwie. Jedynie poprzez dyskusję, wyjaśnianie dogłębne spraw wiary i rozumienia funkcjonowania Kościołów chrześcijańskim przybliża nas do jedności. Jest wiele spraw ciągle inaczej rozumianych przez Kościoły chrześcijańskie, ale tylko na drodze dyskusji, takiego np. sympozjum, jakie miało miejsce w uniwersytecie w Eichstätt-Ingolstadt, a teraz wydane w formie książkowej, można wiele wyjaśnić i przybliżyć stanowiska w sprawach wiary i jedności. Pozycja książkowa dokumentuje treści przedstawionych referatów, czuje się jednak niedosyt z braku dyskusji, której ta publikacja nie zawiera. Jest to jednak ważne dzieło i godne polecenia także polskim ekumenistom i członkom różnych gremiów ds. dialogu pomiędzy chrześcijańskimi wyznaniami.

Ks. Mieczysław Olszewski 